\title{
ANTIBACTERIAL ACTIVITIES OF XANTHIUM STRUMARIUM L.
}

\author{
ANJANA DEVKOTA ${ }^{1} \bowtie$ AND RITU KUMARI DAS ${ }^{1}$ \\ ${ }^{1}$ Central Department of Botany Tribhuvan University, Kirtipur, Kathmandu, Nepal \\ devkotaa@gmail.com
}

\section{ABSTRACT}

Antibacterial activities of Xanthium strumarium L. (Asteraceae) was carried out in laboratory. Distilled water and methanol extracts of the leaves of plant was prepared. The antibacterial activity was studied against six pathogenic bacteria, three gram negative: Klebsiella pneumoniae (ATCC 15380), Proteus mirabilis (ATCC 49132), Escherichia coli (ATCC 25922) and three gram positive: Bacillus subtilis (ATCC 6633), Enterococcus faecalis (ATCC 29212), Staphylococcus aureus (ATCC 25932) at different concentrations $(50 \mathrm{mg} / \mathrm{ml}, 100 \mathrm{mg} / \mathrm{ml}, 150 \mathrm{mg} / \mathrm{ml}, 200 \mathrm{mg} /$ $\mathrm{ml}, 250 \mathrm{mg} / \mathrm{ml}$ ) of leaf extracts of $X$. strumurium. The phytochemical screening depicted the presence of terpenoids, saponins, flavonoids, tannins and alkaloids. The antibacterial activity of extracts was determined by disc diffusion method and zone of inhibition (ZOI) was measured. Gram negative bacteria was found more resistant than gram positive bacteria. The most susceptible bacterium was $S$. aureus while the most resistant bacterium was $E$. coli. Methanolic extract was found more effective than distilled water. These findings suggest that extracts obtained from leaves of $X$. strumurium possess biobactericidal potential, which can suitably be exploited for making antibacterial drugs.

Keywords: IAS, antibacterial property, ZOI, LMGR, phytochemical screening

\section{INTRODUCTION}

Xanthium strumarium L. (rough cocklebur), is a species of annual plants belonging to the Asteraceae family. It is found to be problematic in agricultural field. Plant is also found to be dominating in roadsides and open dry pastures (Tiwari et al., 2005). The principal compounds isolated from $X$. strumarium include xanthanol, isoxanthanol, hydroquinone, caffeyolquinic acids, alkaloids, and thiazinedione (Han et al., 2007; Ying-Tsun et al., 1998). The plant may have some medicinal properties and has been used in traditional medicine in south Asia and traditional Chinese medicine. All parts of plant possess sedative, diaphoretic and diuretic properties. Extracts of whole plant parts especially leaves, roots, fruits and seeds have traditional medicinal value and used mainly for the treatment of poisonous insects bites, epileosy, leucoderma (Kamboj \& Saluja, 2010). The plant also shows its efficacy in mitigating longstanding cases of malarial fever (Sharma, 2003). Some biological properties of $X$. strumarium $L$. have been reported, such as antiulcerogenic, anthelmintic (Sharma, 2003), anti-inflammatory, diuretic, antileishmanial, antifungal (Kamboj \& Saluja 2010) and a significant depressant action on the central nervous system (Mandal et al., 2001).

However, there are no reports about the antibacterial activities of $X$. strumarium extracts against human pathogenic microorganisms such as Escherichia coli, Klebsiella pneumoniae, Staphyllococcus aureus and Bacillus subtilis. 


\section{MATERIALS AND METHODS}

\section{Collection of plant material and extraction procedure}

The fresh and healthy leaves of $X$. strumarium were collected at the flowering stage from Kirtipur , Kathmandu. The leaves were washed under running tap water and kept under shade on the newspaper till they become completely dry. The completely dried leaves sample was grinded into fine powder with the help of electric grinder and stored in air tight zipper bag.

A fixed weight $(25 \mathrm{~g})$ of dried powdered leaf sample of plant material was soaked separately in $250 \mathrm{ml}$ of methanol (95\%) and distilled water for $72 \mathrm{~h}$. Each mixture was stirred at $24 \mathrm{~h}$ interval using a sterile glass rod (Alagesaboopathi, 2011). The plant samples squeezed and then filtered with the help of triple- layered cotton cloth. Water content of distilled water filtrate was evaporated on heating mantle using water bath till the solution reduced to semisolid form (Bhattarai \& Shrestha, 2009). The round bottom flask containing methanolic extract was fitted with rotary vacuum evaporator under reduced pressure. The flask was constantly heated in rotating condition by using water bath below $55^{\circ} \mathrm{C}$. Extracts were then transferred into sterile labeled bottles and they were made into semisolid form by evaporation to water bath at $50^{\circ} \mathrm{C}$. The crude extracts were weighted and made the bottles air tight and stored in a refrigerator at temperature $4^{\circ} \mathrm{C}$ until further use (Mahida \& Mohan, 2007).

\section{Collection of microorganisms}

Six different bacterial strains were selected. Among them 3 were Gram negative namely Escherichia coli (ATCC 25922), Klebsiella pneumoniae (ATCC 15380) and Proteus mirabilis (ATCC 49132) and 3 were Gram positive viz Enterococcus faecalis (ATCC 29212) Bacillus subtilis (ATCC 6633) and Staphylococcus aureus (ATCC 25923). The bacterial strains used for the test were brought from Department of Microbiology, Teaching hospital, Maharajgunj. They were taken on slants and later cultured in test tube having nutrient broth.

\section{Plant extract concentration}

Different concentrations of the plant leaves extract $(50 \mu \mathrm{g} / \mathrm{ml}, 100 \mu \mathrm{g} / \mathrm{ml}, 150 \mu \mathrm{g} / \mathrm{ml}, 200 \mu \mathrm{g} /$ $\mathrm{ml}$, and $250 \mu \mathrm{g} / \mathrm{ml}$ ) were made in both solvents i.e. methanol and distilled water separately. Methanol and distilled water was used as negative control and Ampicillin and Amoxicillin at 10 $\mathrm{mg} / \mathrm{ml}$ were introduced as positive control (Oyedeji et al., 2010).

\section{Antibacterial test}

Inhibition of bacterial growth was tested by using disc diffusion method (Peach \& Tracey, 1950). The test disc ( $5 \mathrm{~mm}$ diameter) was made by punching the filter paper Sartorious stedium 292. For this Nutrient Agar media was applied ( $\mathrm{HI}$ media method recommended). It was poured almost $10-10 \mathrm{ml}$ in each sterilized petriplates and was left to solidify for 15-20 minutes. The Nutrient agar plates for the assay were prepared by drawing in each petriplates six chambers and labeling them with the date, code name of the bacteria and the concentrations code. The inoculums of bacteria were transferred into petriplates containing solidified media using sterile cotton swab. The sterile cotton swab was dipped into well mixed distilled water test culture and was spread on the media by moving the swab in $Z$-shape. One swab was used for single bacterium. Seven replicates were used for each bacterium. The culture plates were allowed 
to dry for 5-10 minutes. Then in each petriplate in each chamber different concentrated and controls disc were put with the help of sterile forceps. The plates were then incubated at $37^{\circ} \mathrm{C}$ for $24 \mathrm{~h}$. Microbial growth was determined by measuring the diameter of zone of inhibition (ZOI).

\section{Phytochemical screening}

Phytochemical screening of the extracts was done for saponins, tannins, alkaloids, terpenoids, and flavonoids using standard phytochemical screeningmethods with slight change.

\section{Qualitative analysis}

Preliminary qualitative phytochemical screening was carried out on aqueous and methanol extract applying the standard protocols described by Sofowara (1993), Trease \& Evans (1989), \& Harborne (1973) and for the result sharp change in color was noted.

Terpenoids (Salkowski test): five $\mathrm{ml}$ of each extract was mixed in $2 \mathrm{ml}$ of chloroform, and 3 $\mathrm{ml}$ of concentrated $\mathrm{H}_{2} \mathrm{SO}_{4}$ was added carefully to form a layer. A reddish brown colouration of the inter face was formed to show positive results for the presence of terpenoids.

Saponin: One gram of the powered samples were boiled in $10 \mathrm{ml}$ of water and methanol separately in a water bath and filtered. Five $\mathrm{ml}$ of the filtrate was mixed with $2.5 \mathrm{ml}$ of distilled water and shaken vigorously for a stable persistent froth.

Steroids: Five $\mathrm{ml}$ of extract was taken and to it few drops of acetic anhydride and $5 \mathrm{ml}$ of chloroform was added. Finally few drops of $\mathrm{H}_{2} \mathrm{SO}_{4}$ was added slowly along the wall of test tube. Green bluish colour indicated the presence of steroids.

Flavonoids: Five $\mathrm{ml}$ of dilute ammonia solution were added to a portion of the aqueous filtrate of plant extract followed by addition of concentrated $\mathrm{H}_{2} \mathrm{SO}_{4}$. A yellow coloration observed in extract indicated the presence of flavonoids. The yellow coloration disappeared after some time.

Tannins: About $0.5 \mathrm{~g}$ of the dried powered sample was boiled in $20 \mathrm{ml}$ of water in a test tube and then filtered. A few drops of $0.1 \%$ ferric chloride was added and observed for brownish green or a blue-black colouration.

Alkaloid: Plant sample of $200 \mathrm{mg}$ was taken in $10 \mathrm{ml}$ methanol and was filtered. Mayer's Test: In $2 \mathrm{ml}$ filtrate $1 \% \mathrm{HCL}$ was added and was steamed and $1 \mathrm{ml}$ of filtrate was treated with 6 drops of Mayer's reagents. Formation of yellow coloured precipitate indicated the presence of alkaloids. Wagner's Test: Filtrate was treated with Wagner reagent. Formation of brown/ reddish coloured precipitate indicated the presence of alkaloids. Dragondroff's Test: Filtrate was treated with Dragondroff's reagents formation of red coloured precipitate indicated the presence of alkaloids.

\section{Data analysis}

The values were expressed as mean \pm standard deviation (SD). Each value was a mean of seven replicates. The One - way Analysis of Variance (ANOVA) was used to determine the significant differences between the parameters and the Tukey HSD test was done to compare the differences between different concentration at $p<0.05$ using statistical package SPSS version 16. 


\section{RESULTS AND DISCUSSION}

\section{Antibacterial activity}

Methanolic extract of $X$. strumarium was able to show zone of inhibition with K.pneumoniae, $E$. faecalis, B. subtilis, P.mirabilis, S. aureus but it was ineffective against $E$. coli (table 1). Similarly, distilled water extract of $X$. strumarium was able to show zone of inhibition with $E$. faecalis, B.subtilis, P. mirabilis, S. aureus and it was incapable with E. coli and K. pneumoniae (table 2). Similar result was found by Malik et al. (2012). According to their result the leaf extract of $X$. strumarium in different solvents (aqueous, ethanol and n-hexane) only inhibited $S$. aureus and it was not able to inhibit E. coli, K. pneumoniae and B. subtilis. Khuda et al. (2012) were found that the extract of chloroform of $X$. strumarium inhibited $S$. aureus, $B$. subtilis and $E$. coli and ethyl acetate extract inhibited $S$. aureus. But no inhibition of any bacterial growth was observed by aqueous extract. This differences in result may be due to the difference in time of collection of plant material, difference of solvent and habitat of plant material.

The data were expressed as Mean $\pm S$. D. and statistically analysis using One Way ANOVA for obtaining $\mathrm{F}$ and $\mathrm{P}$ value. For each fungal strains significance between mean among different concentrations are indicated by different letters (Tukey HSD multiple comparison test, $P<0.05$.

TABLE 1. Zone of Inhibition (ZOI) $\mathrm{mm}$ in methanol leaf extract of Xanthium strumarium.

\begin{tabular}{|l|l|l|l|l|l|l|l|l|l|}
\hline & \multicolumn{4}{|c|}{ Concentrations (mg/ml) } & \multicolumn{3}{c|}{ Control } & \\
\hline $\begin{array}{l}\text { Bacterial } \\
\text { strain }\end{array}$ & 50 & 100 & 150 & 200 & 250 & \multicolumn{2}{l|}{ Negative } & Positive & \\
\cline { 6 - 10 } & & & & & Meth. & Ampi. & Amox. & $\mathrm{P}$ \\
\hline K.p. & $25 \pm .1 \mathrm{~b}$ & $26 \pm 1 \mathrm{~b}$ & $26 \pm 1 \mathrm{~b}$ & $28 \pm 1 \mathrm{~b}$ & $30 \pm 1 \mathrm{~b}$ & $0 \pm 0 \mathrm{a}$ & $37 \pm 4 \mathrm{c}$ & $29 \pm 7 \mathrm{~b}$ & .000 \\
\hline E.f. & $9 \pm .9 \mathrm{~b}$ & $10 \pm .9 \mathrm{~b}$ & $11 \pm 1 \mathrm{~b}$ & $11 \pm .7 \mathrm{~b}$ & $11 \pm 1 \mathrm{~b}$ & $0 \pm 0 \mathrm{a}$ & $34 \pm .4 \mathrm{~d}$ & $26 \pm 4 \mathrm{c}$ & .000 \\
\hline E.coli & $0 \pm 0 \mathrm{a}$ & $0 \pm 0 \mathrm{a}$ & $0 \pm 0 \mathrm{a}$ & $0 \pm 0 \mathrm{a}$ & $0 \pm 0 \mathrm{a}$ & $0 \pm 0 \mathrm{a}$ & $33 \pm 4 \mathrm{~b}$ & $33 \pm 4 \mathrm{~b}$ & .000 \\
\hline B.s. & $25 \pm .7 \mathrm{~b}$ & $26 \pm .5 \mathrm{~b}$ & $26 \pm .7 \mathrm{~b}$ & $27 \pm .6 \mathrm{~b}$ & $28 \pm .4$ & $0 \pm 0 \mathrm{a}$ & $28 \pm 7 \mathrm{~b}$ & $24 \pm 4 \mathrm{~b}$ & .000 \\
\hline P. $m$. & $6 \pm 0 \mathrm{~b}$ & $6 \pm 0 \mathrm{~b}$ & $6 \pm .4 \mathrm{~b}$ & $7 \pm .3 \mathrm{~b}$ & $8 \pm .2 \mathrm{~b}$ & $0 \pm 0 \mathrm{a}$ & $27 \pm 1 \mathrm{~d}$ & $21 \pm 1 \mathrm{c}$ & .000 \\
\hline S.a. & $25 \pm .7 \mathrm{~b}$ & $25 \pm .6 \mathrm{~b}$ & $26 \pm 1 \mathrm{~b}$ & $26 \pm 1 \mathrm{~b}$ & $27 \pm 1 \mathrm{~b}$ & $0 \pm 0 \mathrm{a}$ & $26 \pm 7 \mathrm{~b}$ & $21 \pm 11 \mathrm{~b}$ & .000 \\
\hline
\end{tabular}

Abbreviations:K.p.=Klebsiella pneumoniae; E.f. $=$ Enterococcus faecalis; E.coli=Escherichia coli; B.s. =Bacillus subtilis; P.m. =Proteus mirabilis; S. $a .=$ Staphylococcus aureus; Ampi=Ampicillin; Amoxi=Amoxicillin, values are mean \pm SD of seven replicate

Among the tested plants the highest zone of inhibition; $25 \mathrm{~mm}-30 \mathrm{~mm}$ diameter at $50 \mathrm{mg} / \mathrm{ml}$ to $250 \mathrm{mg} / \mathrm{ml}$ concentration was showed by methanolic extract of $X$. strumarium on bacteria K. pneumoniae. On $B$. subtillis and $S$. aureus, this plant showed $Z O I 25 \mathrm{~mm}-28 \mathrm{~mm}$ and 25 $\mathrm{mm}-27 \mathrm{~mm}$ diam at $50 \mathrm{mg} / \mathrm{ml}$ to $250 \mathrm{mg} / \mathrm{ml}$ concentration respectively (table 1). This may be due to the antibacterial substances present in it may have higher diffusibility. There are also reports on the antibacterial activity of xanthanolides isolated mostly from $X$. srtumarium (Gupta \& Gupta, 1975). X. strumarium did not show effect on $E$. coli at both methanolic extract and 
distilled water at $50-250 \mathrm{mg} / \mathrm{ml}$ concentrations. K. pneumoniae also didn't show inhibition with it in D/W (table 2). With no antibacterial activities, extract may be active against other bacterial species which were not tested (Shale et al., 1999). Lack of activities can thus only be proven by using large doses (Farnsworth, 1993).

The data were expressed as Mean $\pm S$. D. and statistically analysis using One Way ANOVA for obtaining $F$ and $P$ value. For each bacterial strains significance between mean among different concentrations are indicated by different letters (Tukey HSD multiple comparison test, $P<0.05$.

TABLE 2. Zone of Inhibition (ZOI) $\mathrm{mm}$ in distilled water leaf extract of Xanthium strumarium.

\begin{tabular}{|c|c|c|c|c|c|c|c|c|c|}
\hline \multirow{3}{*}{$\begin{array}{l}\text { Bacterial } \\
\text { strain }\end{array}$} & \multicolumn{5}{|c|}{ Concentrations } & \multicolumn{3}{|c|}{ Control } & \multirow[b]{3}{*}{$P$} \\
\hline & \multirow[t]{2}{*}{50} & \multirow[t]{2}{*}{100} & \multirow[t]{2}{*}{150} & \multirow[t]{2}{*}{200} & \multirow[t]{2}{*}{250} & \multirow{2}{*}{$\begin{array}{l}\text { Negative } \\
\text { DW }\end{array}$} & \multicolumn{2}{|l|}{ Positive } & \\
\hline & & & & & & & Ampi. & Amox. & \\
\hline K.p. & $0 \pm 0$ a & $0 \pm 0$ a & $0 \pm 0$ a & $0 \pm 0 \mathrm{a}$ & $0 \pm 0$ a & $0 \pm 0$ a & $37 \pm 4 \mathrm{c}$ & $29 \pm 7 b$ & .000 \\
\hline E.f. & $9 \pm 1 b$ & $11 \pm 2 \mathrm{bc}$ & $12 \pm 3 b c$ & $14 \pm 4 \mathrm{bc}$ & $16 \pm 4 \mathrm{c}$ & $0 \pm 0$ a & $34 \pm .4 \mathrm{e}$ & $26 \pm 4 d$ & .000 \\
\hline E.coli & $0 \pm 0$ a & $0 \pm 0$ a & $0 \pm 0 \mathrm{a}$ & $0 \pm 0$ a & $0 \pm 0 \mathrm{a}$ & $0 \pm 0$ a & $33 \pm 4 b$ & $33 \pm 4 b$ & .000 \\
\hline B.s. & $12 \pm 1 b$ & $13 \pm 1 b$ & $14 \pm 2 b$ & $16 \pm 2 b$ & $17 \pm 2 b$ & $0 \pm 0$ a & $28 \pm 7 \mathrm{~b}$ & $24 \pm 7 \mathrm{~b}$ & .000 \\
\hline P. $m$. & $6 \pm 0 \mathrm{~b}$ & $6 \pm 0 \mathrm{~b}$ & $6 \pm 0 \mathrm{~b}$ & $6 \pm 0 \mathrm{~b}$ & $6 \pm .2 \mathrm{~b}$ & $0 \pm 0$ a & $27 \pm 1 d$ & $21 \pm 1 c$ & .000 \\
\hline S.a. & $0 \pm 0$ a & $0 \pm 0$ a & $0 \pm 0$ a & $6 \pm 1 a$ & $6 \pm .3 a$ & $0 \pm 0$ a & $26 \pm 7$ b & $21 \pm 11 b$ & .000 \\
\hline
\end{tabular}

Abbreviations:K.p.=Klebsiella pneumoniae; E.f. $=$ Enterococcus faecalis; E.coli=Escherichia coli; B.s.=Bacillus subtilis; P.m. =Proteus mirabilis; S.a.=Staphylococcus aureus; Ampi=Ampicillin; Amoxi=Amoxicillin, values are mean \pm SD of seven replicates.

The diameter of ZOI produced depends on several factors broadly classified as extrinsic or intrinsic parameters. The extrinsic parameters like $\mathrm{pH}$ of the medium, period and temperature of incubation, volume of well, concentration of plant extracts and size of inoculums can be fixed and standard during experiment hence no error results due to extrinsic factors. Intrinsic factors such as methods of plants including its components, solubility and diffusion property are predetermined (Prasai et al., 2008).

In comparison, gram positive bacteria were found more susceptible than gram negative bacteria of the crude extracts. Similar type of result has shown by Matu \& Van Staden (2003), Parekh \& Chanda (2007). These differences may be attribute to the fact that, the cell wall in gram positive bacteria are of single layered whereas that of gram negative bacteria are multilayered (Yao et al., 1995). The methanol extract had the highest activity against bacterial isolates; this may be attributed to the presence of soluble phenolic and polyphenolic compounds. Phenols have been found to be useful in the preparation of some antimicrobial compounds such as Dettol and cresol (Kowalski \& Kedzia, 2007).Comparison of the efficacy of the extract with commercial antibiotics had shown that in some cases the plant extract is more effective in 
inhibiting the growth of the organisms than the antibiotics. This may be due to the presence of stronger bioactive principles in the plant extract and its molecular size which permit its penetration into the cells of the organisms (Oladunmoye, 2006).

\section{Phytochemical screening}

As the plant produce secondary metabolites in order to protect themselves from microorganism, herbivores and insects, thus antimicrobial effect is somehow expected from plants namely flavonoids, alkaloids, tannins, saponins and tri-terpenoids are producing a better opportunity for testing wide range of microorganism (Arora \& Kumar, 2012).

The phytochemical screening test had shown the presence of active chemical constituents such as terpenoids, saponins, flavonoids, tannins, and alkaloids.

TABLE 3. Preliminary phytochemical screening of leaf extract of Xanthium strumarium.

\begin{tabular}{|l|l|l|}
\hline Phytochemical group & Solvents \\
\hline & Distilled water & Methanol \\
\hline Terpenoids & +++ & +++ \\
\hline Saponins & ++ & +++ \\
\hline Flavonoids & - & +++ \\
\hline Tannins & - & + \\
\hline Alkaloids & ++ & +++ \\
\hline
\end{tabular}

Responses to various tests were denoted by,+++ and +++ signs indicating weak, moderate and strong reactions respectively while - for no reaction.

Distilled water extract of $X$. strumarium leaves revealed the presence of high concentration of terpenoids (table 3); while its methanolic extract of revealed the presence of high concentration of terpenoids, saponins, flavonoids and alkaloids. Sravani \& Laxshmi (2012) found that the methanol, aqueous and petroleum ether extracts of $X$. strumarium revealed the presence of flavonoids and steroids but negative results were obtained for alkaloids, terpenoids, tannins, glycosides and saponins. The result is somewhat dissimilar with this present study. This dissimilar result may be due to a large extent, the phenological stage of the plant, percentage humidity of the harvested material, situation and time of harvest, and the method of extraction and solvent used (Felix, 1982).

Both distilled water and methanol extracts had shown varying degrees of antibacterial activities on the microorganisms tested. The chance to find antibacterial activity was more apparent in methanol than distilled water extracts of $X$. strumarium.

The present study has demonstrated that the antibacterial activity of $X$. strumarium. This work proves that some invasive plant species like $X$. strumarium have potential and could be useful in combating microbial pathogens. Phyto-compounds are also expected to be more advantageous than synthetic chemicals for their steer magnitude of complexity, diversity and 
novelty of chemicals since they may be biodegradable in nature, non-pollutant and may possess no residual or phytotoxic properties.

\section{REFERENCES}

ALAGESABOOPATHI, C (2011) Antimicrobial potential and phytochemical screening of Andrographis affinis Nees an endemic medicinal plant from India. International Journal of Pharmacy and Pharmaceutical Sciences 3 (2): 157-159.

ARORA, S; KUMAR, D S (2012) Phytochemical, antimicrobial and antioxidant activities of methanol extract of leaves and flowers of Ipomoea cairica. International Journal of Pharmacy and Pharmaceutical Sciences 5(1): 198-201.

BHATTARAI, N; SHRESTHA, G (2009) Antibacterial and antifungal effect of Eupatoreum adenophorum Spreng against bacterial and fungal isolates. Nepal Journal of Science and Technology 10: 91-95.

FARNSWORTH, N R (1993) Biological approaches to the screening and evaluation of natural products. In RASOANAIVO, P; RATSIMAMANGA-URVERG, S (eds) Biological evaluation of plants with reference to the Malagasy flora, Madagascar; pp 35-43.

FELIX, M T (1982) Medical Microbiology. Churchill Livingstone (Publishers), London, UK; pp 445-459.

GUPTA, K; GUPTA, D (1975) Isolation of an antibacterial compound, xanthium from the leaves of Xanthium strumarium. Linn. Journal of The Indian Chemical Society 52: 1224-1225.

HAN, T; LI, H L ; ZHANG, Q Y; HAA, P; ZHENG, H C; RAHMANAND, K; QIN, L P (2007) Bioactivity guided fractionation for anti-inflammatory and analgesic properties and constituents of Xanthium strumarium L. Phytomedical 14: 825-829.

HARBORNE, J B (1973) Phytochemicals Methods. Chapman and Hall Ltd., London, UK; pp 49-188.

KAMBO, J A; SALUJA, A K (2010) Phytopharmacological review of Xanthium strumarium L. (Cocklebur) .International Journal of Green Pharmacy 4 (3): 129-139.

KALIMUTHU, K; VIJAYAKUMAR, S; SENTHILKUMAR, R (2010) Antimicrobial activity of the biodiesel plant, Jatrophacurcas. International Journal of Pharmaceutical Biological Science 1: 1-5.

KHUDA, F; IQBAL, Z; KHAN, A; ZAKIULLAH NASIR, F; KHAN, M S (2012) Validation of some of the ethnopharmacological uses of Xanthium strumarium and Duchesneaindica. Pakistan Journal of Botany 44(4): 1201-12012.

KOWALSKI, R; KEDZIA, B (2007) Antibacterial activity of Silphium perfoliatum extracts pharmaceutical Biology 45: 495-500.

MAHIDA, Y; MOHAN, J S S (2007) Screening of plants for their potential antibacterial activity against Staphylococcus and Salmonella spp. Natural Product Radiance 6 (4): 301-305.

MALIK F; HUSSAIN, S; MIRZA, T; HAMEED, A; AHMAD, S; RIAZ, H; SHAH, P A; USMANGHANI, K (2012) Screening for antimicrobial activity of thirty-three medicinal plants used in the tradicinal system of medicine in Pakistan. Journal of Medicinal plants research 5 (14): 3052-3060.

MATU, E N; VAN STADEN, J (2003) Antibacterial and anti-inflammatory activities of some plants used for medicinal purposes in Kenya. Journal of Ethnopharmacology 87: 35-41.

OLADUNMOYE, M K (2006) Comparative evaluation of antimicrobial activities and phytochemical screening of two varieties of Acalypha wilkesiana. International Journal of Tropical Medicine 1(3): 134-136. 
OYEDEJI O; OZIEGBE, M; TAIWO, F O (2010) Antibacterial, antifungal and phytochemical analysis of crude extracs from the leaves of Ludwigiadecurrens Walter. Journal of Medicinal plantsResearch 5 (7): 1192-1199.

PAREKH, J; CHANDA, D (2007) In vitro antibacterial activity of crude methanol extract of Woodfordia fruticosa Kurz flower (Lythacease). Brazilian Journal of Microbiolgy 38: 204-207.

PRASAI, T; YAMI, K D; BAJRACHARYA, A M; BASNYAT, S R; LEKHAK, B (2008) Screening of some medicinal plants used in Nepalese traditional medicinal against enteric bacteria. Scientific World 6(6): 107-110.

PEACH, K; TRACEY, M V (1950) Modern methods of plant analysis. Springer-verlag Berlin 2: 645.

SHALE, T L; STIRK, W A; STADEN, J V (1999) Screening of medicinal plants used in Lesotho for antibacterial and anti-inflammatory activity. Journal of Ethnopharmacology 67: 347-354.

SHARMA, R (2003) Medicinal plants of India, Daya Publishing House, Dehli, India; 5 p.

SINGH , G; KUMAR A, P; JINDAL, A (2012) Antibacterial potential of sterols of some medicinal plants. International Journal of Pharm Science 4 (3): 159-162.

SOFOWARA, A (1993) Medicinal plants and traditional medicine in Africa. Spectrum books limited, Nigeria; pp 191-289.

SRAVANI, P; LAXSHMI, S M (2012) Pharmacognostic and phytochemical profiles of Xanthium strumarium L. (Asteraceae). Journal of pharmaceutical biology 2 (1): 20-34.

TIWARI, S; ADHIKARI, B SIWAKOTI, M; SUBEDI, K (2005) An inventory and assessment of invasive alien plant species of Nepal. IUCN Nepal, Kathmandu.

TREASE, G E; EVANS, W C (1989) Pharmacognocy, BailliereTindall, London, UK; pp 45-50. (11 th $^{\text {th }}$ edition).

YAO, J; MOELLERING, R (1995) Antibacterial agents. In MURRAYA, P; BARON, E; PFALLER, M; TENOVER, F; YOLKEN, R (eds) Manual of Clinical Microbiology. ASM,Washington DC, USA; pp 1281-1290.

YING-TSUN, M A; MU-CHI, H; FENG-LIN C, H; HSIU-FONG (1998) Thiazinedione from Xanthium strumarium. Phytochemistry 48: 1083-1085. 